\title{
ETIKA PERDAGANGAN DALAM ISLAM
}

Hajarudin Ahmad ${ }^{1}$, Muhammad Arsyam²

${ }^{1}$ Sekolah Tinggi Agama Islam (STAI) Darul Dakwah Wal-Irsyad (DDI) Kota Makassar, Indonesia Email: hjrahmad09@gmail.com

${ }^{2}$ Sekolah Tinggi Agama Islam (STAI) Darul Dakwah Wal-Irsyad (DDI) Kota Makassar, Indonesia Email: arsyam0505@gmail.com

\begin{abstract}
Abstrak
Islam memang menghalalkan usaha perdagangan, perniagaan dan atau jual beli. Namun tentu saja untuk orang yang menjalankan usaha perdagangan secara Islam, dituntut menggunakan tata cara khusus, ada aturan mainnya yang mengatur bagaimana seharusnya seorang Muslim berusaha di bidang perdagangan agar mendapatkan berkah dan ridha Allah SWT di dunia dan akhirat.
\end{abstract}

\section{Pendahuluan}

Aturan main perdagangan Islam, menjelaskan berbagai etika yang harus dilakukan oleh para pedagang Muslim dalam melaksanakan jual beli. Dan diharapkan dengan menggunakan dan mematuhi etika perdagangan Islam tersebut, suatu usaha perdagangan dan seorang Muslim akan maju dan berkembang pesat lantaran selalu mendapat berkah Allah SWT di dunia dan di akhirat. Etika perdagangan Islam menjamin, baik pedagang maupun pembeli, masing-masing akan saling mendapat keuntungan.

Adapun etika perdagangan Islam tersebut antara lain:

\section{Shidiq (Jujur)}

Seorang pedagang wajib berlaku jujur dalam melakukan usaha jual beli. Jujur dalam arti luas. Tidak berbohong, tidak menipu, tidak mengada-ngada fakta, tidak bekhianat, serta tidak pernah ingkar janji dan lain sebagainya. Mengapa harus jujur? Karena berbagai tindakan tidak jujur selain merupakan perbuatan yang jelas-jelas berdosa, -jika biasa dilakukan dalam berdagang- juga akan mewarnal dan berpengaruh negatif kepada kehidupan pribadi dan keluarga pedagang itu sendiri. Bahkan lebih jauh lagi, sikap dan tindakan yang seperti itu akan mewarnai dan mempengaruhi kehidupan bermasyarakat.

Dalam Al Qur'an, keharusan bersikap jujur dalam berdagang, berniaga dan atau jual beli, sudah diterangkan dengan sangat jelas dan tegas yang antara lain kejujuran tersebu -di beberapa ayat- dihuhungkan dengan pelaksanaan timbangan, sebagaimana firman Allah SWT: "Dan sempurnakanlah takaran dan timbangan dengan adil". (Q.S Al An'aam(6): 152)

Firman Allah SWT:

"Sempurnakanlah takaran dan janganlah kamu termasuk orang-orang yang merugikan, dan timbanglah dengan timbangan yang lurus. Dan janganlah kamu merugikan manusia pada hak-haknya dan janganlah kamu merajalela di muka bumi ini dengan membuat kerusakan." (Q.S AsySyu'araa(26): 181-183) 
"Dan sempurnakanlah takaran apabila kamu menakar, dan timbanglah dengan neraca yang benar. ItuIah yang lebih utama (bagimu) dan lebih baik akibatnya." (Q.S Al lsraa(17): 35)

"Dan tegakkanlah timbangan itu dengan adil dan janganlah kamu mengurangi neraca itu." (Q.S Ar Rahmaan(55): 9)

Dengan hanya menyimak ketiga ayat tersebut di atas, maka kita sudah dapat mengambil kesimpulan bahwa; sesungguhnya Allah SWT telah menganjurkan kepada seluruh ummat manusia pada umumnya, dan kepada para pedagang khususnya untuk berlaku jujur dalam menimbang, menakar dan mengukur barang dagangan. Penyimpangan dalam menimbang, menakar dan mengukur yang merupakan wujud kecurangan dalam perdagangan, sekalipun tidak begitu nampak kerugian dan kerusakan yang diakibatkannya pada manusia ketimbang tindak kejahatan yang lehih besar lagi seperti; perampokan, perampasan, pencu rian, korupsi, manipulasi, pemalsuan dan yang lainnya, nyatanya tetap diharamkan oleh Allah SWT dan Rasul-Nya. Mengapa? Jawabnya adalah; karena kebiasaan melakukan kecurangan menimbang, menakar dan mengukur dalam dunia perdagangan, akan menjadi cikal baka! dari bentuk kejahatan lain yang jauh lebih besar. Sehingga nampak pula bahwa adanya pengharaman serta larangan dari Islam tersebut, merupakan pencerminan dan sikap dan tindakan yang begitu bijak yakni, pencegahan sejak dini dari setiap bentuk kejahatan manusia yang akan merugikan manusia itu sendiri.

Di samping itu, tindak penyimpangan dan atau kecurangan menimbang, menakar dan mengukur dalam dunia perdagangan, merupakan suatu perbuatan yang sangat keji dan culas, lantaran tindak kejahatan tersebut bersembunyi pada hukum dagang yang telah disahkan baik oleh pemerintah maupun masyarakat, atau mengatasnamakan jua! beli atas dasar suka sama suka, yang juga telah disahkan oleh agama.

Jika penampokan, pencurian, pemerasan, perampasan, -sudah jelas- merupakan tindakan memakan harta orang lain dengan cara batil, yang dilakukan dengan jalan terang-terangan. Namun tindak penyimpangan dan atau kecurangan dalam menimbang, menakar dan mengukur barang dagangan, merupakan kejahatan yang dilakukan secara sembunyi-sembunyi. Sehingga para pedagang yang melakukan kecurangan tersebut, pada hakikatnya adalah juga pencuri, perampok dan perampas dan atau penjahat, hanya mereka bersembunyi di balik lambang keadilan yakni, timbangan, takaran dan ukuran yang mereka gunakan dalam perdagangan. Dengan demikian, tidak ada bedanya! Mereka sama-sama penjahat. Maka alangkah kejinya tindakan mereka itu. Sehingga wajar, jika Allah SWT dan Rasul-Nya mengharamkan perbuatan tersebut, dan wajar pula jika para pelakunya diancam Allah SWT; akan menerima azab dan siksa yang pedih di akhirat kelak, sebagaimana Firman Allah SWT dalam Al Qur'an:

"Kecelakaan besarlah bagi orang-orang yang curang, (yaitu) orang-orang yang apabila menerima takaran dari orang lain, mereka minta dipenuhi, dan apabila mereka menakar atau menimbang untuk orang lain, mereka mengurangi. Tidakkah orang-orang 
ini menyangka, bahwa sesungguhnya mereka akan dibangkitkan, pada suatu hari yang besar, (yaitu) hari (ketika) manusia berdiri menghadap Tuhan Semesta Alam ini." (Q.S Al Muthaffifiin (83): 1-6)

Selain ancaman azab dan siksa di akhirat kelak -bagi orang-orang yang melakukan berbagai bentuk penyimpangan dan kecurangan dalam menakar, menimhang dan mengukur barang dagangan mereka-, sesungguhnya Al Qur'an juga telah menuturkan dengan jelas dan tegas kisah onang-orang Madyan yang terpaksa harus menerima siksa dunia dari Allah SWT, lantaran menolak peringatan dari Nabi mereka Syuaib as.

"Dan (Kami telah mengutus) kepada penduduk Madyan saudara mereka Syuaib. Ia berkata:"Hai kaumku, sembahlah Allah, sekali-kali tidak ada Tuhan bagimu selain-Nya. Sesungguhnya telah datang kepadamu bukti yang nyata dari Tuhanmu. Maka sempurnakanlah takaran dan timbangan dan janganlah membuat kerusakan di muka bumi sesudah Tuhan memperbaikinya. Yang demikian itu lebih baik bagimu jika betulbetul kamu orang-orang yang beriman". (Q.S Al A'raaf(7): 85)

Firman Allah SWT:

"Dan tatkala datang azab Kami, Kami selamatkan Syuaib dan orang-orang yang beriman bersama-sama dia dengan Rahmat dari Kami, dan orang-orang yang zalim dibinasakan oleh satu suara yang mengguntur, lalu jadilah mereka mati bergelimpang an di temnat tinggalnya." (Q.S Hud(11): 94)

Kedua ayat tersebut di atas, hendaknya menjadi peringatan bagi kita, bahwa ternyata perbuatan curang dalam menimbang, menakar dan mengukur barang dagangan, sama sekali tidak memberikan keuntungan, kehahagiaan bagi para pelakunya, bahkan hanya menimbulkan murka Allah. Sedangkan azab dan siksa serta hukuman bagi para pelaku kejahatan tersebut, nyatanya tidak selalu diturunkan Allah SWTI kelak dii akhirat saja, namun juga diturunkan di dunia.

Oleh sebab itu, Rasulullah SAW -dalam banyak haditsnya-, kerapkali mengingatkan para pedagang untuk berlaku jujur dalam berdagang.

Sabda Rasulullah SAW:

"Wahai para pedagang, hindarilah kebohongan". (HR. Thabrani)

"Seutama-utama usaha dari seseorang adalah usaha para pedagang yang bila berbicara tidak berbohiong, bila dipercaya tidak berkhianat, bila berjanji tidak ingkar, bila membeli tidak menyesal, bila menjual tidak mengada -gada, bila mempunyai kewajiban tidak menundanya dan bila mempunyai hak tidak menyulitkan". (HR. Ahmad, Thabrani dan Hakim)

"Pedagang dan pembeli keduanya boleh memilih selagi belum berpisah. Apabila keduanya jujur dan terang-terangan, maka jual belinya akan diberkahi. Dan apabila keduanya tidak rnau berterus terang serta berbohong, maka jual belinya tidak diberkahi." (HR. Bukhari dan Muslim)

Rasulullah SAW menegaskan pula, bahwa pedagang yang jujur dalam melaksakan jual beli, di akhirat kelak akan ditempatkan di tempat yang mulia. Suatu ketika akan 
bersama- sama para Nabi dan para Syahid. Suatu ketika di bawah Arsy, dan ketika lain akan berada di suatu tempat yang tidak terhalang baginya masuk ke dalam surga.

Sabda Rasulullah SAW:

"Pedagang yang jujur serta terpercaya (tempatnya) bersama para Nabi, orang-orang yang jujur, dan orang-orang yang mati Syahid pada hari kiamat”. (HR. Bukhari, Hakim, Tirmidzi dan Ibnu Majjah)

"Pedagang yang jujur di bawah Arsy pada hari kiamat". (HR. Al-Ashbihani)

"Pedagang yang jujur tidak terhalang dari pintu-pintu surga". (HR. Tirmidzi)

Allah Ta'ala berfirman (dalam hadits Qudsi):

"Aku yang ketiga (bersama) dua orang yang berserikat dalam usaha (dagang) selama yang seorang tidak berkhianat (curang) kepada yang lainnya. Apabila berlaku curang, maka Aku keluar dari mereka." (HR. Abu Dawud)

"Sesama Muslim adalah saudara. Oleh karena itu seseorang tidak boleh menjual barang yang ada cacatnya kepada saudaranya, namun ia tidak menjelaskan cacat tersebut." (HR. Ahmad dan lbnu Majaah)

"Tidak halal bagi seseorang menjual sesuatu barang dengan tidak menerangkan (cacat) yang ada padanya, dan tidak halal bagi orang yang tahu (cacal) itu, tapi tidak menerangkannya." (HR. Baihaqie)

"Sebaik-baik orang Mu'min itu ialah, mudah cara menjualnya, mudah cara membelinya, mudah cara membayarnya dan mudah cara menagihnya." (HR. Thabarani)

\section{Amanah (Tanggungjawab)}

Setiap pedagang harus bertanggung jawab atas usaha dan pekerjaan dan atau jabatan sebagai pedagang yang telah dipilihnya tersebut. Tanggung jawab di sini artinya, mau dan mampu menjaga amanah (kepercayaan) masyarakat yang memang secara otomatis terbeban di pundaknya.

Sudah kita singgung sebelumnya bahwa -dalam pandangan Islam- setiap pekerjaan manusia adalah mulia. Berdagang, berniaga dan ataujual beli juga merupakan suatu pekerjaan mulia, lantaran tugasnya antara lain memenuhi kebutuhan seluruh anggota masyarakat akan barang dan atau jasa untuk kepentingan hidup dan kehidupannya.

Dengan demikian, kewajiban dan tanggungjawab para pedagang antara lain: menyediakan barang dan atau jasa kebutuhan masyarakat dengan harga yang wajar, jumlah yang cukup serta kegunaan dan manfaat yang memadai. Dan oleh sebab itu, tindakan yang sangat dilarang oleh Islam -sehubungan dengan adanya tugas, kewajiban dan tanggung jawab dan para pedagang tersebut- adalah menimbun barang dagangan.

Menimbun barang dagangan dengan tujuan meningkatkan pemintaan dengan harga selangit sesuai keinginan penimbun barang, merupakan salah satu bentuk kecurangan dari para pedagang dalam rangka memperoleh keuntungan yang berlipat ganda.

Menimbun barang dagangan -terutama barangbarang kehutuhan pokok- dilarang keras oleh Islam! Lantaran perbuatan tersebut hanya akan menimbulkan keresahan dalam 
masyarakat. Dan dalam prakteknya, penimbunan barang kebutuhan pokok masyarakat oleh sementara pedagang akan menimbulkan atau akan diikuti oleh berhagai hal yang negatifseperti; harga-harga barang di pasar melonjak tak terkendali, barang-barang tertentu sulit didapat, keseimbangan permintaan dan penawaran terganggu, munculnya para spekulan yang memanfaatkan kesempatan dengan mencari keuntungan di atas kesengsaraan masyarakat dan lain sebagainya.

Ada banyak hadits Rasulullah yang menyinggung tentang penimbunan barang dagangan, baik dalam bentuk peringatan, larangan maupun ancaman, yang .ntara lain sebagai berikut:

Sabda Rasulullah (yang artinya):

"Allah tidak akan berbelas kasihan terhadap orang-orang yang tidak mempunyai belas kasihan terhadap orang lain." (HR. Bukhari)

"Barangsiapa yang melakukan penimbunan terhadap makanan kaum Muslimin, Allah akan menimpanya dengan kerugian atau akan terkena penyakit lepra." (HR. Ahmad)

"Orang yang mendatangkan barang dagangan untuk dijual, selalu akan memperoleh rejeki, dan orang yang menimbun barang dagangannya akan dilaknat Allah." (HR. lbnu Majjah)

"Barangsiapa yang menimbun makanan, maka ia adalah orang yang berdosa." (HR. Muslim dan Abu Daud)

"Barangsiapa yang menimbun makanan selama 40 hari, maka ia akan lepas dari tanggung jawab Allah dan Allah pun akan cuci tangan dari perbuatannya." (HR. Ahmad)

\section{Tidak Menipu}

Dalam suatu hadits dinyatakan, seburuk-buruk tempat adalah pasar. Hal ii lantaran pasar atau termpat di mana orang jual beli itu dianggap sebagal sebuah tempat yang di dalamnya penuh dengan penipuan, sumpah palsu, janji palsu, keserakahan, perselisihan dan keburukan tingkah polah manusia lainnya.

Sabda Rasulullah SAW:

"Sebaik-baik tempat adalah masjid, dan seburk-buruk tempat adalah pasar". (HR. Thabrani)

"Siapa saja menipu, maka ia tidak termasuk golonganku”. (HR. Bukhari)

Setiap sumpah yang keluar dan mulut manusia harus dengan nama Allah. Dan jika sudah dengan nama Allah, maka harus benar dan jujur. Jika tidak henar, maka akibatnya sangatlah fatal.

Oleh sehab itu, Rasulululah SAW selalu memperingatkan kepada para pedagang untuk tidak mengobral janji atau berpromosi secara berlebihan yang cenderung mengadangada, semata-mata agar barang dagangannya laris terjual, lantaran jika seorang pedagang berani bersumpah palsu, akibat yang akan menimpa dirinya hanyalah kerugian.

Sabda Rasulullah SAW: 
"Jangan bersumpah kecuali dengan nama Allah. Barangsiapa bersumpah dengan nama Allah, dia harus jujur (benar). Barangsiapa disumpah dengan nama Allah ia harus rela (setuju). Jika tidak rela (tidak setuju), niscaya lepaslah ia dari pertolongan Allah." (HR. lbnu Majaah dan Aththusi)

"Ada tiga kelompok orang yang kelak pada hari kiamat Allah tidak akan berkata-kata, tidak akan melihat, tidak akanpula mensucikan mereka. Bagi mereka azab yang pedih. Abu Dzarr berkata, "Rasulullah mengulang-ulangi ucapannya itu, dan aku hertanya," Siapakah mereka itu, ya Rasulullah?” Beliau menjawab, "Orang yang pakaiannya menyentuh tanah karena kesombongannya, orang yang menyiarkan pemberiannya (mempublikasikan kebaikannya), dan orang yang menjual dagangannya dengan sumpah palsu." (HR. Muslim)

"Sumpah dengan maksud melariskan barang dagangan adalah penghapus barokah." (HR. Bukhari dan Muslim)

"Sumpah (janji) palsu menjadikan barang dagangan laris, (tetapi) menghapus keberkah an”. (HR. Tirmidzi, Nasal dan Abu Dawud)

"Berhati-hatilah, jangan kamu bersumpah dalam penjualan. Itu memang melariskan jualan tapi menghilangkan barokah (memusnahkan perdagangan)." (HR. Muslim)

Sementara itu, apa yang kita alami selama ini, jual beli, perdagangan dan atau perniagaan di zaman sekarang -terutama di pasar-pasar bcbas- tidak banyak lagi diketemukan orang yang mau memperhatikan etiket perdagangan Islam. Bahkan nyaris, setiap orang -penjual maupun pembeli- tidak mampu lagi membedakan barang yang halal dan yang haram, dimnana keadaan ini sesungguhnya sudah disinyalir akan terjadi oleh Rasulullah SAW, sebagaimana dinyatakan dalam haditsnya.

Dari Abu Hurairah, dari Nabi SAW, bersabda: “Akan datang pada manusia suatu zaman yang seseorang tidak memperhatikan apakah yang diambilnya itu dan barang yang halal atau haram." (HR. Bukhari)

Memang sangat disayangkan, mengapa hal seperti ini harus terjadi? Sementara tidak hanya sekali saja Rasulullah SAW memberi peringatan kepada para pedagang untuk berbuat jujur, tidak menipu dalam berjual beli agar tidak merugikan orang lain. Sehagaimana pernyataan beberapa hadits di bawah ini:

Dari Abu Hurairah berkata, Rasulullah SAW bersabda: "Janganlah seseorang menjual akan suatu barang yang telah dibeli oleh orang lain”. (HR. Bukhari)

Dari lbnu Umar: Bahwa seorang laki-laki menyatakan pada Nabi SAW bahwa ia tertipu ketika berjual heli. Maka Nabi menyatakan: "Jika engkau berjualbeli maka katakanlah: Tidak boleh menipu”. (HR. Bukhari)

\section{Menepati Janji}

Seorang pedagang juga dituntut untuk selalu menepati janjinya, baik kepada para pembeli maupun di antara sesama pedagang, terlebih lagi tentu saja, harus dapat menepati janjinya kepada Allah SWT. 
Janji yang harus ditepati oleh para pedagang kepada para pembeli misalnya; tepat waktu pengiriman, menyerahkan barang yang kwalitasnya, kwantitasnya, warna, ukuran dan atau spesifikasinya sesuai dengan perjanjian semula, memberi layanan puma jual, garansi dan lain sebagainya. Sedangkan janji yang harus ditepati kepada sesama para pedagang misalnya; pembayaran dengan jumlah dan waktu yang tepat.

Sementara janji kepada Allah yang harus ditepati oleh para pedagang Muslim misalnya adalah shalatnya. Sebagaimana Firman Allah dalam Al Qur'an:

"Apabila telah ditunaikan shalat, maka bertebaranlah kamu di muka bumi; dan carilah karunia Allah dan ingatlah Allah banyak-banyaknya supaya kamu beruntung. Dan apabila mereka melihat perniagaan atau permainan, mereka bubar untuk menuju kepadaNya dan mereka tinggalkan kamu sedang berdiri (berkhutbah). Katakanlah: "Apa yang di sisi Allah adalah lebih baik daripada permainan dan perniagaan", dan Allah sebaik-baik pemberi rezki" (Q.S Al Jumu'ah (62):10-11)

Dengan demikian, sesibuk-sibuknya urusan dagang, urusan bisnis dan atau urusan jual beli yang sedang ditangani -sebagai pedagang Muslim- janganlah pernah sekali-kali meninggalkan shalat. Lantaran Allah SWT masih memberi kesempatan yang sangat luas kepada kita untuk mencari dan mendapatkan rejeki setelah shalat, yakni yang tercermin melalui perintah-Nya; bertebaran di muka bumi dengan mengingat Allah SWT banyakbanyak supaya beruntung.

\section{Murah Hati}

Dalam suatu hadits, Rasulullah SAW menganjurkan agar para pedagang selalu bermurah hati dalam melaksanakan jual beli. Murah hati dalam pengertian; ramah tamah, sopan santun, murah senyum, suka mengalah, namun tetap penuh tanggungjawab.

Sabda Rasulullah SAW:

"Allah berbelas kasih kepada orang yang murah hati ketika ia menjual, bila membeli dan atau ketika menuntut hak". (HR. Bukhari)

"Allah memberkahi penjualan yang mudah, pembelian yang mudah, pembayaran yang mudah dan penagihan yang mudah". (HR. Aththahawi)

\section{Tidak Melupakan Akhirat}

Jual beli adalah perdagangan dunia, sedangkan melaksanakan kewajiban Syariat Islam adalah perdagangan akhirat. Keuntungan akhirat pasti lebih utama ketimbang keuntungan dunia. Maka para pedagang Muslim sekali-kali tidak boleh terlalu menyibukkan dirinya semata-mata untuk mencari keuntungan materi dengan meninggalkan keuntungan akhirat. Sehingga jika datang waktu shalat, mereka wajib melaksanakannya sebelum habis waktunya. Alangkah baiknya, jika mereka bergegas bersama-sama melaksanakan shalat berjamaah, ketika adzan telah dikumandangkan. Begitu pula dengan pelaksanaan kewajiban memenuhi rukun Islam yang lain. Sekali-kali seorang pedagang Muslim hendaknya tidak melalaikan kewajiban agamanya dengan alasan kesibukan perdagangan. 


\section{Kesimpulan}

Sejarah telah mencatat, bahwa dengan berpedoman kepada etika perdagangan Islam sebagaimana tersebut di atas, maka para pedagang Arab Islam tempo dulu mampu mengalami masa kejayaannya, sehinga mereka dapat terkenal di hampir seluruh penjuru dunia.

\section{Daftar Pustaka}

https://www.kompasiana.com/firawardani49207/5c7dd39dab12ae109e7e8a64/prinsipetika-berdagang-anjuran-rasulullah-saw, 5 Maret 2019

Faisal Badroen , Etika Bisnis Dalam Islam. (Jakarta: Kencana, 2006)

Hamzah Ya'kub, Etika Islam, (Bandung: CV. Diponegoro, 1991), Cet-5

Asmaran As, Pengantar Studi Akhlak, (Jakarta: Pt. Raja Grapindo Persada, 2002), cet. $\mathrm{Ke}-3$

Depertemen Agama RI, Al-Qur'an dan Terjemahnya, (Bandung: PT. Syaamil Cipta Media)

https://republika.co.id/berita/p7jh9c313/etika-berdagang-saudagar-muslim-di-masakejayaan Sabtu 21 Apr 2018

Zamzam, H. F., \& Aravik, H. (2020). Etika Bisnis Islam Seni Berbisnis Keberkahan. Deepublish.

Hasan, N. F. (2017). KONSEP DAN IMPLEMENTASI ETIKA ISLAM DALAM DUNIA BISNIS. ISTITHMAR: Journal of Islamic Economic Development

Arsyam, M., \& Kusnadi Umar, Z. Z. MANUSIA SEBAGAI PENDIDIK PERPEKTIF ISLAM DAN BARAT.

Sapada, A. O., \& Arsyam, M. (2020). Ilmu Pengetahuan dan Teknologi Menurut Pandangan Islam.

Arsyam, M., \& Sainuddin, I. H. Meraih Surga dengan Sabar dan Syukur.

Zakirah, Z., Jumliadi, J., Arsyam, M., Herianto, H., Rusli, M., \& Alwi, A. M. Implementation of The Islamic Local Regulations in Bulukumba Regency.

Jumliadi, J., Zakirah, Z., Arsyam, M., Alwi, A. M. S., \& Fadhil, M. PEMBELAJARAN DIRUMAH DALAM LINGKUNGAN KELUARGA DI TENGAH PANDEMI COVID 19.

HERIANTO, H. (2020). Pengaruh Kesehatan Mental, Keaktifan Berorganisasi Dan Prestasi Akademikterhadap Tingkat Pemahaman Moderasi Beragama.

S Syarfaini, S Alam, S Aeni, H Habibi, NA Novianti. Faktor Risiko Kejadian Anemia Pada Ibu Hamil Di Wilayah Kerja Puskesmas Sudiang Raya Kota Makassar - Alsihah: The Public Health Science Journal, 2020 
